\title{
Instrumentos de Avaliação em Reumatologia: Importância de sua Tradução e Validação para nosso Idioma
}

1 grande maioria dos instrumentos de avaliação de qualidade de vida foi formulada na língua inglesa. Em virtude do crescente número de ensaios clínicos multicêntricos, criou-se a necessidade de se desenvolver medidas delineadas especificamente para utilização em países cujo idioma não é o inglês, e para populações de imigrantes que adotaram a língua inglesa. Nessas duas situações, diferenças culturais importantes podem estar presentes. Isso pode ser feito de duas formas: desenvolver uma nova medida ou traduzir e adaptar culturalmente uma medida previamente validada em outro idioma.

A primeira opção demanda um consumo maior de tempo e empenho, tanto pessoal como financeiro, para proceder-se a criação de um novo instrumento, adequando novos conceitos, selecionando seus itens e testando sua validade. Além disso, é importante avaliar a real necessidade de se criar um novo instrumento quando já existe um preparado anteriormente com o mesmo intuito e boa qualidade.

Na segunda opção, entretanto, também não basta que o instrumento seja simplesmente traduzido, é necessário que se faça uma avaliação rigorosa de sua tradução e adaptação cultural, bem como uma avaliação de suas propriedades de medida após este processo. Dispomos na literatura de alguns guias para a sua realização, que incluem a tradução, retrotradução (back-translation) e pré-teste para a adaptação cultural, enfatizando a análise das equivalências semânticas, idiomáticas, culturais e conceituais. Todas as etapas devem ser supervisionadas por um grupo de pessoas cientes do método e da proposta do instrumento.

É importante ressaltar que, após a tradução e adap- tação cultural de qualquer instrumento, considerando que neste processo sempre acontecem algumas modificações, este deve ter suas propriedades de medida, ou seja, confiabilidade, validade e sensibilidade às alterações testadas, mesmo que tais propriedades já tenham sido demonstradas com o instrumento original.

A tradução e validação para o português brasileiro de dois instrumentos importantes, um para avaliação de desordens do ombro e outro da consagrada escala de Lequesne, estão sendo oferecidos à comunidade reumatológica brasileira nesse volume da Revista Brasileira de Reumatologia (RBR). Esperamos que nossos leitores façam bom proveito e que esses instrumentos possam auxiliar no tratamento dos seus pacientes.

Nesse volume, também trazemos um extenso estudo da avaliação clínica e laboratorial dos pacientes com espondiloartropatias seronegativas acompanhados na Universidade Federal de Minas Gerais (UFMG), em Belo Horizonte, um dos Serviços com maior experiência nessas desordens no Brasil. Outro centro que vem colaborando intensamente com a RBR, o de Curitiba, traz a sua interessante experiência sobre o padrão de acometimento articular em pacientes com lúpus eritematoso sistêmico.

Boa leitura a todos.

Lais V. Lage e Roger A. Levy Editores Científicos da RBR

Rozana M. Ciconelli Universidade Federal de São Paulo (UNIFESP) 